\title{
Effect of micronutrient supplementation on linear growth of children
}

\author{
Nita Bhandari*, Rajiv Bahl and Sunita Taneja \\ All India Institute of Medical Sciences, Ansari Nagar, New Delhi 110029, India
}

\begin{abstract}
This review summarizes the results of published, randomized clinical trials that have examined the impact of administration of micronutrients, singly or in combination to infants, preschool and school children on linear growth. Supplementation of single micronutrients resulted in small or no benefits on linear growth. A meta-analysis of zinc supplementation trials confirmed that zinc has a significant but small impact ( $0 \cdot 22$ SD units) on length gain in children $0-13$ years of age. However, a recent study reported a substantially greater benefit ( $>1 \mathrm{SD})$ in stunted and nonstunted breast-fed infants 6-12 months of age. With iron supplementation, a beneficial effect was found only in anemic children. Vitamin A supplementation trials have reported little or no benefit on linear growth. Data currently available suggest some impact in children with clinical or biochemical vitamin A deficiency, but this issue needs confirmation. Few studies could be identified where a combination of micronutrients was given as a supplement or as fortified food; in the latter set of studies energy availability was assured. The impact on length without multiple micronutrient supplementation was no greater than that observed with single micronutrients. In conclusion, zinc and iron seem to have a modest effect on linear growth in deficient populations. Vitamin A is unlikely to have an important effect on linear growth. Limited available evidence does not allow us to conclude whether a combination of micronutrients, with or without additional food, would have a greater impact than that seen with zinc alone.
\end{abstract}

Linear growth: Iron: Vitamin A: Zinc: Micronutrients

Linear growth faltering is common in children belonging to the low socio-economic groups in developing countries. This faltering commences during the intrauterine period and extends to postnatal life, most strikingly in the initial 18-24 months. Subsequently, the rates of growth approach those of children in industrialized countries (Waterlow et al. 1980).

The aetiology of linear growth faltering is thought to be multi-factorial. Maternal malnutrition and low dietary intakes in infants, frequent infections and poor psychosocial environment are some factors known to be associated with retarded linear growth.

Macro or micronutrient deficiency during the prenatal period could potentially programme the fetus towards slower linear growth during postnatal life or result in low nutrient stores at birth. Low micronutrient intakes of young infants in developing countries could result from low levels of various micronutrients in breast milk due to maternal deficiency, and also from inadequate complementary feeding practices during the second half of infancy. Energy as well as micronutrient intakes of infants are usually low in many of these settings. Even when energy intakes are adequate, diets are often vegetarian and are low in content and poor in bioavailability of nutrients like iron, calcium, zinc and vitamin A. Developing country infants and children suffer frequent infections leading to decreased intake, impaired absorption, increased nutrient losses, hypercatabolism and other metabolic perturbations, all of which contribute to faltered linear growth.

The micronutrients associated with linear growth are those believed to be nutritionally significant or 'essential'; reduction in the availability of these micronutrients below a certain threshold consistently leads to a reduction in one or more physiologically important functions. These 'essential' micronutrients have been defined by a WHO Expert Committee to include iodine, zinc, selenium, copper, molybdenum, chromium, vitamin $\mathrm{A}$ and calcium (WHO, 1996).

This review is focused on the role of deficiency of micronutrients in linear growth faltering of developing country infants in postnatal life and the extent to which supplementation of these micronutrients, alone or in combination, improves growth. The evidence available from observational as well as experimental studies is examined. This issue assumes importance given the recent proposals to consider routine supplementation of multinutrient mixtures as a strategy to reduce stunting in developing country children.

\section{Supplementation trials with individual micronutrients} Zinc

Zinc deficiency has long been known to be associated with high phytate, high fiber, low protein diets and with 
hookworm and schistosomiasis (Halstead et al. 1972). The initial zinc supplementation trials, conducted in the early 1980s did not result in improved linear growth possibly because of the short duration of supplementation and poor absorption of zinc due to vegetarian diets that impeded absorption (Allen, 1994). Recent studies, several of which were done in industrialized countries, have however shown improved linear growth following zinc supplementation.

A meta-analysis of twenty-two zinc supplementation trials with concurrent controls that examined impact on linear growth was recently published (Brown et al. 1998). Most of the included studies were double-blind and placebo-controlled. The age range of children participating in these trials that examined the impact of zinc supplementation on linear growth was from birth to 13 years; the mean age was 3.6 years. The mean initial plasma zinc of children ranged from 42 to $140 \mu \mathrm{g} / \mathrm{dL}$ (mean $83 \mu \mathrm{g} / \mathrm{dL}$ ). The duration of supplementation varied from 10 days to 16 months, with an average of approximately 7 months. Between eleven and 191 subjects per group were enrolled in the trials. The initial height for age Z-scores ranged from -5.4 to +0.12 with a mean of $-2 \cdot 32$. The mean daily zinc dose was $14 \mathrm{mg}$ per day with a range of $1.5 \mathrm{mg}$ to $50 \mathrm{mg}$. In most studies, zinc was administered 5 to 6 days a week.

The results of all studies were standardized as 'effect size' which was calculated as the mean change in length/ height of the treatment group minus the mean change in the control group divided by the pooled standard deviation of change for both groups. Overall, zinc supplementation resulted in a significant but small average effect size of $0 \cdot 22$ SD units.

There was a significant heterogeneity in effect size in the studies. Initial height for age status of infants and children was found to be associated with treatment effect size in a multiple regression analysis. In studies with mean initial height for age Z-score less than -2 , there was a larger effect size of 0.49 SD units. No impact of supplementation was observed in studies with mean initial height for age $\mathrm{Z}$-score greater than -2 .

In a recent randomized double-blind zinc supplementation trial, not included in the meta-analysis, 100 nonstunted and 100 stunted breast-fed infants, 6-12 months of age, received $10 \mathrm{mg}$ zinc or placebo 6 days a week for 6 months. The effect size was 4.32 SD for stunted and 1.88 SD for non-stunted infants (Umeta et al. 2000). These 8-9 fold greater effect sizes than those in the meta-analysis may be due to higher level of zinc deficiency, larger dose of zinc used and the supplemental period being that of rapid growth. These results, however, need to be confirmed in future studies.

In conclusion, zinc is an important linear growth limiting micronutrient in populations that are zinc deficient.

\section{Vitamin A}

Association between linear growth faltering and clinical vitamin A deficiency signs (night blindness, conjunctival xerosis) prompted intervention trials examining the impact of vitamin A supplementation on linear growth (Mele et al. 1991; Brink et al. 1979; Santos et al. 1983; Muhilal et al. 1988).

We identified ten vitamin A supplementation trials from published literature that have reported an impact on linear growth. Seven of these studies were double-blind, placebocontrolled and included children aged from 6 months to 5 years. Vitamin A was given weekly (Rahmathullah et al. 1991) as a single large dose (Bahl et al. 1997) or 4-6 monthly (Lie et al. 1993; Ramakrishnan et al. 1995; Fawzi et al. 1997; West et al. 1997; Donnen et al. 1998, Hadi et al. 2000) supplements, or as fortified monosodium glutamate (Muhilal et al. 1988). Two studies did not have random allocation; neighbouring villages (Muhilal et al. 1988) and alternate households (Fawzi et al. 1997) were given vitamin A or placebo in these. One study did not report the overall effect; there was however no benefit of supplementation in either males or females in terms of linear growth (West et al. 1988). In the remaining nine studies, effect sizes were calculated as SD shifts as suggested by Brown et al. (1998). The effect sizes ranged from -0.06 to $+0.21 \mathrm{SD}$; the median was $0.05 \mathrm{SD}$ (Table 1). Only two of the ten studies showed a significant but small benefit of 0.16 and 0.21 SD (Muhilal et al. 1988; Hadi et al. 2000). Both these studies were from Indonesia where vitamin A deficiency was very common; $1.24 \%$ had Bitot's spots in one study and $67.4 \%$ had serum retinol $\leq 0.7 \mu \mathrm{mol} / \mathrm{L}$ in the other. The latter study also showed that the benefit was 2-3 fold higher in infants who had serum retinol $\leq 0.35 \mu \mathrm{mol} / \mathrm{L}$.

The evidence available to date suggests that routine vitamin A supplementation has little or no impact on linear

Table 1. Impact of vitamin A supplementation on linear growth

\begin{tabular}{|c|c|c|c|c|c|}
\hline Author, year & $\begin{array}{l}\text { Subjects' age } \\
\text { (months) }\end{array}$ & $\begin{array}{l}\text { Number† } \\
\text { per group }\end{array}$ & Vitamin A & Comments on study design & $\begin{array}{l}\text { Effect size } \\
\text { (SD units) }\end{array}$ \\
\hline Muhilal, 1988 & $12-23$ & $322 / 361$ & Fortified monosodium glutamate & $\begin{array}{l}\text { Non-random, five neighbouring } \\
\text { villages selected as control }\end{array}$ & $0 \cdot 16^{\star}$ \\
\hline Rahmathullah, 1991 & $12-23$ & $1136 / 1171$ & $2500 \mu \mathrm{g}$ RE weekly for 1 year & Randomized, double-blind & 0.12 \\
\hline Lie, 1993 & $6-36$ & $94 / 94$ & $60000 \mu \mathrm{g} \mathrm{RE}$; two doses. 6 months apart & Randomized, double-blind & $0 \cdot 19$ \\
\hline Ramakrishnan, 1995 & $6-36$ & $310 / 282$ & $60000 \mu \mathrm{g}$ RE; three doses every 4 months & Randomized, double-blind & 0.05 \\
\hline Fawzi, 1997 & $6-72$ & $10625 / 10626$ & $60000 \mu \mathrm{g}$ RE; three doses every 6 months & Alternate household allocation & 0.03 \\
\hline West, 1997 & $12-60$ & $1760 / 1617$ & $60000 \mu \mathrm{g} \mathrm{RE;} \mathrm{four} \mathrm{doses} \mathrm{every} 4$ months & Randomized, double-blind & 0.03 \\
\hline Bahl, 1997 & $12-59$ & $427 / 430$ & $60000 \mu \mathrm{g}$ RE; single dose & Randomized, double-blind & 0.05 \\
\hline Donnen, 1998 & $0-72$ & $118 / 117$ & $60000 \mu \mathrm{g}$ RE; two doses every 4 months & Randomized, double-blind & -0.06 \\
\hline Hadi, 2000 & $6-48$ & $715 / 722$ & $61800 \mu \mathrm{g}$ RE; six doses every 4 months & Randomized, double-blind & $0.21^{*}$ \\
\hline
\end{tabular}

* $P<0.05 ; \dagger$ intervention/control. 


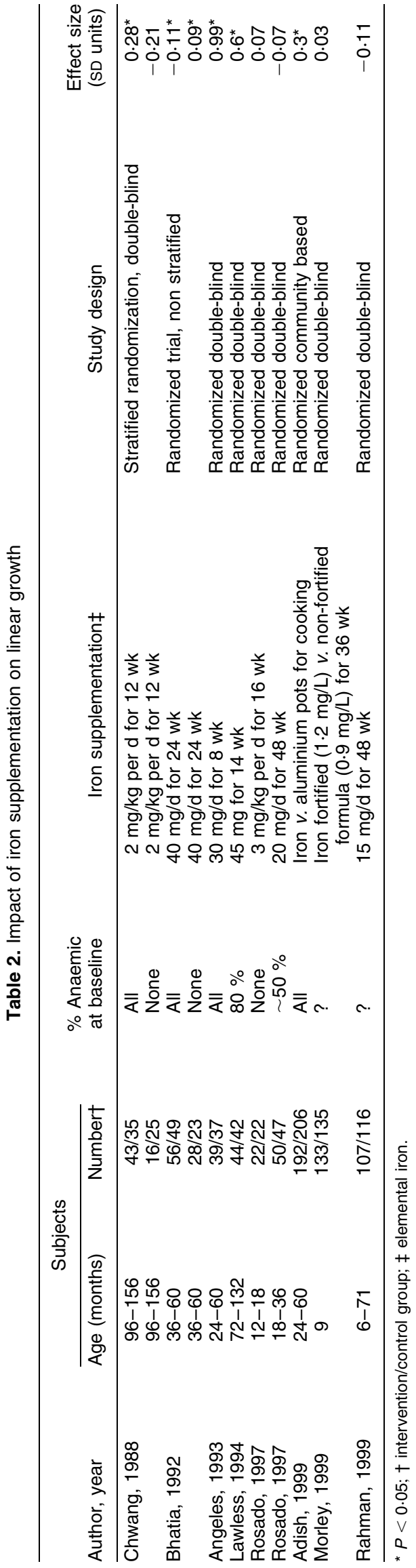

growth. The data are not sufficient to allow any conclusion on impact of vitamin A in children with clinical or biochemical deficiency.

\section{Iron}

There are several small iron supplementation studies that have examined its impact on linear growth in young children. These studies appear to have mixed results with the effect sizes varying from -0.21 to +0.99 SD units (Adish et al. 1999; Angeles et al. 1993; Lawless et al. 1994; Morley et al. 1999; Rahman et al. 1999). The results become clearer when the studies are classified by baseline prevalence of anaemia (Table 2). Four of the five studies, where $>80 \%$ children were anaemic, showed significant benefits in linear growth following supplementation (median effect size 0.6 SD units). An Indian study reported a negative effect in anaemic children and a beneficial impact in those who were non-anaemic (Bhatia \& Seshadari, 1992). The design of this study had several limitations. Four preschools were randomly allocated without stratification by haemoglobin status, but results were presented separately for anaemic and non-anaemic children. Further, there were important baseline differences in length, which were not adjusted for. In studies where the prevalence of anaemia was either not mentioned or was low, no impact was observed.

Similarly, none of the studies in anaemic iron replete children reported a beneficial impact of iron supplementation. On the contrary there is some suggestion that growth might be adversely affected under these circumstances (Idjradinata et al. 1994). Non significant negative effects were reported for length $(-0.21 \mathrm{SD}$ units) in a study by Chwang et al. 1988 and on weight in a recent Indonesian study (-0.45 SD units, Idjradinata et al. 1994).

In conclusion, iron supplementation of anaemic children has significant impact on linear growth only in anaemic children. The adverse impact observed in supplementation of non-anaemic children needs further confirmation.

\section{Copper}

Copper deficiency during infancy and childhood is caused by low birth weight, low copper intake because of a predominantly cow's milk-based diet, malabsorption and diarrhea. We could not locate any randomized supplementation trials that examined impact on linear growth. Observational studies suggest that stunted children are copper deficient (Singla et al. 1996; Chuwa et al. 1996; Tanzer \& Ozalp, 1988; Subotzky et al. 1992). In a study from Chile, copper deficient (plasma copper $<70 \mu \mathrm{g} / \mathrm{dL}$ and ceruloplasmin $<200 \mathrm{mg} / \mathrm{L}$ ) infants $6-12$ months of age and controls matched by age, sex and nutritional status were supplemented with $80 \mathrm{mg} / \mathrm{kg}$ per day copper for one month. Supplementation improved length for age by $0 \cdot 34$ SD units in the copper deficient group and by 0.09 SD in controls but the difference was not significant (CastilloDuran \& Uauy, 1988).

Copper supplementation trials in infants and children with sample size and period of supplementation adequate to examine impact on linear growth are required. 
Observational studies suggest that severe as well as marginal iodine deficiency is associated with linear growth retardation (Greene, 1980; Neumann et al. 1992). There are however, no controlled studies of iodine supplementation with linear growth as the outcome. Such trials are unlikely to be conducted in future because of universal salt iodization recommendations for iodine deficient populations.

\section{Calcium, phosphorus and magnesium}

Evidence from animal studies and observational studies in children suggest that inadequate dietary intakes of calcium may contribute to linear growth retardation. An Indian study conducted in 1938 reported a height gain of $0.36 \mathrm{~cm}$ in 3.6-year-old children supplemented with $65 \mathrm{mg}$ calcium per day for 4-5 months (Aykroyd \& Krishnan, 1938). The same investigators reported $0.53 \mathrm{~cm}$ greater height gain in 6-12-year-old children supplemented with $130 \mathrm{mg}$ calcium for 3 months (Aykroyd \& Krishnan, 1939). These findings were however not confirmed in subsequently conducted controlled supplementation trials in India, China and South Africa (Bansal et al. 1964; Lee et al. 1994; Pettifor et al. 1981). A recent review concluded that calcium supplementation alone or together with phosphorus does not improve height or weight gain of children in developing countries with low to medium calcium intakes (Prentice \& Bates, 1994).

Malnourished children have been reported to have low magnesium levels (Singla et al. 1998). Hypomagnesemia in malnourished children may be due to inadequate intake, malabsorption, diarrhea and other infections. In twentythree Guatemalan children with edematous protein caloric malnutrition following magnesium supplementation $(2.7 \mathrm{mg} / \mathrm{kg}$ per day) for a period of 9-35 days, the rate of recovery from malnutrition was accelerated by two weeks (Nichols et al. 1978). However, more trials are needed to show whether malnourished children will have accelerated linear growth if supplemented with magnesium.

Individual micronutrient supplementation studies in humans have generally observed a smaller impact than that anticipated by the results of animal experiments. One reason is that the deficiency that is achieved in animals is severe as compared to the marginal deficiency observed in humans. Another important factor may be that multiple nutrient deficiencies are likely to occur in children in developing countries and supplementation with individual micronutrients can be expected to have only a limited impact on growth. Studies in various settings have shown that deficiencies of iron, vitamin A, zinc and other micronutrients often coexist (Rosado et al. 1997; Rosado, 1999; Hautvast et al. 1999; Neumann \& Harrison, 1994). The subsequent section therefore, reviews available literature on randomized controlled trials where multiple micronutrients were administered as supplements to observe their impact on linear growth. In another set of studies, foods were fortified with micronutrients to understand the likely impact of micronutrient supplementation on 
linear growth if energy and protein availability were assured.

\section{Interventions examining the impact of multiple micronutrients administered as supplements}

Few randomized placebo controlled trials were identified (Table 3, Rosado et al. 1997; Rosado 1999; Thu et al. 1999; Stuijvenberg et al. 1999). No differences in linear growth were observed between the group supplemented with zinc and iron when compared to the placebo in Mexico after 12 months of supplementation (Rosado et al. 1997). The investigators, concluding that lack of impact was probably due to concurrent deficiencies of other micronutrients, conducted another study in the same setting (Rosado, 1999). In the second study, a mixture of micronutrients was given as a supplement to children over a period of 12 months. There was a small significant overall impact (effect size $0.14 \mathrm{SD}$ units) and a greater benefit was observed in supplemented children belonging to the low and medium socio-economic status (effect size 0.24 SD units; Rosado, 1999).

In Vietnam (Thu et al. 1999), children aged 6-24 months received iron (8 $\mathrm{mg}$ elemental), zinc $(5 \mathrm{mg})$, retinol $(333 \mu \mathrm{g})$ and vitamin C (20 mg) for 3 months. Heights were measured at baseline and 3 months post supplementation. In the overall study population, the impact on growth was not significant. Children who were stunted $(\mathrm{HAZ}<-2)$ at the baseline had greater benefit; $0.57 \mathrm{SD}$ units with weekly and 1.04 SD units with daily supplementation.

In only one study (Sandstead et al. 1998) was a direct comparison made between multiple micronutrients and zinc alone. In this study, school children in China were supplemented at three sites with micronutrients without zinc, micronutrients with zinc and zinc alone. The impact was measured as a change in knee height. The impact observed with multiple micronutrients containing zinc seemed larger than that obtained with zinc alone. The results comparing the impact of micronutrients without zinc and with zinc alone were inconsistent. However, these results need to be interpreted with caution as they pertained to only two study sites; the results from the third site were not presented because of local technical problems in measuring heights.

\section{Supplementation with micronutrient fortified foods}

Even when children are provided with micronutrients in adequate amounts, low energy and protein intakes may limit growth. This issue could be studied in food supplementation trials where food was fortified with micronutrients (Table 4). However, in these trials, the comparison groups differed in energy and protein intakes in addition to differences in micronutrient intake. The impact of micronutrients cannot therefore be separated from that of the additional energy or protein quantity or quality.

Four similar randomized controlled trials were conducted in Congo, Senegal, Bolivia and New Caledonia (Simondon et al. 1996, Table 4). Four-month-old infants were randomly allocated to supplement or control groups. The supplemented infants received a cereal-based precooked porridge offered twice daily for 3 months and consumption was monitored. The mean daily consumption of the supplement at different sites varied between 558 and $790 \mathrm{~kJ} / \mathrm{d}$. The length increment was higher in supplemented children by 0.44 SD units in Senegal; no significant impact was observed in other countries. The authors concluded that one of the reasons for not observing an impact was probably the short period of supplementation.

The supplementation period was longer in a recently concluded trial in New Delhi (Bhandari et al. unpublished). A precooked milk cereal mixture fortified with micronutrients was fed to infants from 4 to 12 months of age. Although higher energy and micronutrient intakes were reported in the supplemented children as compared to those not supplemented, no impact was observed on linear growth.

In a Ghanaian study, infants were randomly assigned to receive one of the four foods from 6 to 12 months of age. These foods were weanimix, fortified weanimix (with vitamin A, iron, zinc, copper, calcium, phosphorus and potassium), weanimix enriched with fish powder and fermented maize porridge plus fish powder. No significant

Table 4. Randomized controlled trials examining the impact of micronutrients given along with food on linear growth in children

\begin{tabular}{|c|c|c|c|c|}
\hline Author, year & $\begin{array}{l}\text { Subject age at starting } \\
\text { supplement (months) }\end{array}$ & Number/group $\dagger$ & Intervention & Effect size (SD units) \\
\hline \multirow[t]{4}{*}{ Simondon, 1996} & 4 & Congo 53/67 & $\begin{array}{l}\text { Precooked mixture } v \text {. usual home } \\
\text { foods } \times 3 \text { months } \ddagger\end{array}$ & $-0 \cdot 13$ \\
\hline & & Senegal $53 / 57$ & & $0.44^{*}$ \\
\hline & & Bolivia 65/62 & & 0.29 \\
\hline & & New Caledonia $43 / 47$ & & 0.04 \\
\hline Lartey, 1999 & 6 & $51 / 53$ & $\begin{array}{l}\text { Fortified v/s unfortified } \\
\text { weanimix } \times 6 \text { months }\end{array}$ & 0 \\
\hline Bhandari, unpublished & 4 & $86 / 90$ & $\begin{array}{l}\text { Precooked milk cereal mixture } v \text {. } \\
\text { usual home foods } \times 8 \text { months } \emptyset\end{array}$ & 0.14 \\
\hline
\end{tabular}

\footnotetext{
* $P<0.05$; $†$ intervention/control; $\ddagger$ precooked wheat, maize, millet, soy bean, milk powder soybean oil, sugar mixture, enriched with calcium, phosphorus, potassium, magnesium, iron, copper, manganese, zinc, iodine, selenium. Vitamins $A, B, E, C, B_{6}, B_{12}$, thiamin, riboflavin, niacin, folic acid and pantothenic acid; $\S$ weanimix (cereal legume blend of maize, soybean and groundnuts) fortified with vitamin $A$, iron, zinc, copper, calcium, phosphorus and potassium; ๆ precooked wheat, milk powder, sugar mixture enriched with vitamins $\mathrm{A}, \mathrm{B}, \mathrm{C}, \mathrm{E}, \mathrm{K}, \mathrm{B} 1, \mathrm{~B}_{2}, \mathrm{~B}_{6}, \mathrm{~B}_{12}$, folic acid, nicotinamide, Ca- panthothenate, niacin, CaPO${ }_{4}$, iron, copper, iodine, manganese, zinc and selenium.
} 
differences were reported between the four intervention groups in linear growth. However weight and length Zscores in all the four intervention groups were higher between 9 and 12 months of age when compared to infants who had not participated in the intervention but resided in the same setting (Lartey et al. 1999).

In conclusion, from the limited data available, it does not appear that micronutrients when supplemented in addition to food have a greater benefit on linear growth than when given alone. It may be noted that in a majority of the trials, food availability but not intake could be assured.

\section{Conclusions}

Among individual micronutrients, there is good evidence that zinc supplementation has a modest but significant linear growth impact in preschool and school going children. A beneficial impact of iron supplementation on linear growth seems likely only in anaemic children. On the other hand, a substantial impact by vitamin $\mathrm{A}$ on linear growth in children is unlikely.

Few investigators have examined the impact of multiple micronutrient supplementation on linear growth; comparisons between multiple and single micronutrient supplementation are even more uncommon. The limited available evidence from published studies does not allow us to conclude that supplementation with multiple micronutrients will have a greater impact on growth than is seen, for instance, with zinc alone in developing countries. More double-blind randomized controlled trials with adequate sample sizes and duration of supplementation, and with provision to examine impact on relevant subgroups are required.

Based on the current evidence of the impact on cognition, morbidity and mortality respectively, iron and vitamin A supplementation should be continued. Zinc supplementation or fortification may be considered in populations where the prevalence of deficiency is high, given the observed impact on morbidity and growth; the case would become stronger if mortality trials proposed to be conducted in the near future also show a beneficial impact on child mortality. The feasibility of providing iron and zinc in the same formulation needs to be explored, if necessary, with addition of trace amounts of copper.

\section{References}

Adish AA, Esrey SA, Gyorkos TW, Jean Baptiste J \& Rojhani A (1999) Effect of consumption of food cooked in iron pots on iron status and growth of young children: a randomized trial. Lancet 353, (9154), 712-716.

Allen LH (1994) Nutritional influences on linear growth: a general review. European Journal of Clinical Nutrition 48 (S1), S75-S89.

Angeles IT, Schultink WJ, Matulessi P, Gross R \& Sastroamidjojo S (1993) Decreased rate of stunting among anemic Indonesian preschool children through iron supplementation. American Journal of Clinical Nutrition 58, 339-342.

Aykroyd WR \& Krishnan BG (1938) The effect of calcium lactate on children in a nursery school. Lancet 2, 153-155.

Aykroyd WR \& Krishnan BG (1939) A further experiment on the value of calcium lactate on children in rural community. Indian Journal of Medical Research 52, 219-223.

Bahl R, Bhandari N, Taneja S \& Bhan MK (1997) The impact of vitamin A supplementation on physical growth of children is dependent on season. European Journal of Clinical Nutrition 51, 26-29.

Bansal P, Rau P, Venkatachalam PS \& Gopalan C (1964) Effect of calcium supplementation on children in a rural community. Indian Journal of Medical Research 52, 219-223.

Bhatia D \& Seshadari S (1992) Growth performance in anemia and following iron supplementation. Indian Pediatrics 30, 195 200.

Brink EW, Perera WD, Broske SP, Cash RA, Smith JL, Sauberlich HE \& Bashor MM (1979) Vitamin A status of children in Sri Lanka. American Journal of Clinical Nutrition 32, 84-91.

Brown KH, Peerson JM \& Allen LH (1998) Effect of zinc supplementation on children's growth: a meta-analysis of intervention trials. Bibliotheca Nutritio et Dieta 54, 76-83.

Castillo-Duran C \& Uauy R (1988) Copper deficiency impairs growth of infants recovering from malnutrition. American Journal of Clinical Nutrition 47, 710-714.

Chuwa LM, Mwiruki G, Bilal MG, Mnubhi EK \& Swai AB (1996) Serum iron, zinc, copper and bromine in malnourished children in Dar es Salaam, Tanzania. East African Medical Journal 73 (5 Suppl), S21-S23.

Chwang L, Soemantri AG \& Pollitt E (1988) Iron supplementation and physical growth of rural Indonesian children. American Journal of Clinical Nutrition 47, 496-501.

Donnen P, Brasseur D, Dramaix M, Vertongen F, Zihindula M, Muharmiriza M \& Hennart P (1998) Vitamin A supplementation but not deworming improves growth of malnourished preschool children in Eastern Zaire. Journal of Nutrition 12, 1320-1327.

Fawzi WW, Herrera MG, Willett WC, Nestel P, Amin AE \& Mohamed KA (1997) The effect of vitamin A supplementation on the growth of preschool children in the Sudan. American Journal of Public Health 87, 1359-1362.

Greene LS (1980) Social and biological predictors of physical growth and neurological development in an area where iodine and protein energy malnutrition are endemic. In Social and Biological Predictors of Nutritional Status, Physical Growth and Neurological Development, pp. 223-256. New York: Academic Press.

Hadi H, Stoltzfus RJ, Dibley MJ, Mouton LH, West KP \& Kjolhede CL (2000) Vitamin A supplementation selectively improves the linear growth of Indonesian preschool children: results from a randomized controlled trial. American Journal of Clinical Nutrition 71, 507-513.

Halstead JA, Ronaghy HA \& Abadi P (1972) Zinc deficiency in man. American Journal of Medicine 53, 277-284.

Hautvast JL, van der Heijden LJ, Luneta AK, van Staveren WA, Tolboom JJ \& van Gastel SM (1999) Food consumption of young stunted and non-stunted children in rural Zambia. European Journal of Clinical Nutrition 53, 50-59.

Idjradinata P, Watkins WE \& Pollitt E (1994) Adverse effect of iron supplementation on weight gain of iron replete young children. Lancet 343, 1252-1254.

Lartey A, Manu A, Brown KH, Peerson JM \& Dewey KG (1999) A randomized, community based trial of the effects of improved, centrally processed complementary foods on growth and micronutrient status of Ghanaian infants from 6 to 12 months of age. American Journal of Clinical Nutrition $\mathbf{7 0}$, 391-404.

Lawless JW, Latham MC \& Stephenson LS (1994) Iron supplementation improves appetite and growth in anemic 
Kenyan primary school children. Journal of Nutrition 124, 645-654.

Lee WTK, Leung SSF, Wang S, Xu Y, Zeng W, Lau J, Oppenheimer SJ \& Cheng JCY (1994) Double blind, controlled calcium supplementation and bone mineral accretion in children accustomed to a low-calcium diet. American Journal of Clinical Nutrition 60, 744-750.

Lie C, Ying C, En-Lin W, Brun T \& Geissler C (1993) Impact of large dose vitamin A supplementation on childhood diarrhea, respiratory disease and growth. European Journal of Clinical Nutrition 47, 88-96.

Mele L, West KP, Kusdiono PA, Nendrawati H, Tilden RJ \& Tarwotjo I (1991) Nutritional and household risk factors for xeropthalmia in Aceh, Indonesia: a case control study. American Journal of Clinical Nutrition 53, 1460-1465.

Morley R, Abbott R, Fairweather-Tait S, MacFadyen U, Stephenson T \& Lucas A (1999) Iron fortified follow on formula from 9 to 18 months improves iron status but not development or growth: a randomized trial. Archives of Diseases in Childhood 81, 247-252.

Muhilal, Permeisih D, Idjradinata YR, Muherdiyantiningsih \& Karyadi D (1988) Vitamin A fortified monosodium glutamate and health, growth and survival of children: a controlled field trial. American Journal of Clinical Nutrition 48, 1271-1276.

Neumann C, Bwibo N \& Sigman M (1992) Diet quantity and quality. In Functional Effects on Kenyan Families. Los Angeles, CA: University of California, School of Public Health.

Neumann CG \& Harrison GG (1994) Onset and evolution of stunting in infants and children. Examples from Human Nutrition Collaborative Research Support Program. Kenya and Egypt Studies. European Journal of Clinical Nutrition $\mathbf{4 8}$ (Suppl 1), S90-S102.

Nichols BL, Alvarado J, Hazlewood CF \& Viteri F (1978) Magnesium supplementation in protein calorie malnutrition. American Journal of Clinical Nutrition 31, 176-188.

Pettifor JM, Ross P, Moodley G \& Shuenyane E (1981) The effect of dietary calcium supplementation on serum calcium, phosphorus and alkaline phosphatase concentrations in a rural black population. American Journal of Clinical Nutrition 34, 2187-2191.

Prentice A \& Bates CJ (1994) Adequacy of dietary mineral supply for human bone growth and mineralization. European Journal of Clinical Nutrition 48 (Suppl 1), S161-S176.

Rahman MM, Akramuzzaman SM, Mitra AK, Fuchs GJ \& Mahalanabis D (1999) Long term supplementation with iron does not enhance growth in malnourished Bangladeshi children. Journal of Nutrition 129, 1319-1322.

Rahmathullah L, Underwood BA, Thulasiraj RD \& Milton RC (1991) Diarrhea, respiratory infections and growth are not affected by a weekly low dose vitamin A supplement: a masked, controlled field trial in children in Southern India. American Journal of Clinical Nutrition 54, 568-577.

Ramakrishnan U, Latham MC \& Abel R (1995) Vitamin A supplementation dies not improve growth of preschool children: a randomized, double blind field trial in South India. Journal of Nutrition 125, 202-211.

Rosado JL, Lopez P, Munoz E, Martinez H \& Allen LH (1997) Zinc supplementation reduced morbidity, but neither zinc nor iron supplementation affected growth or body composition of
Mexican preschoolers. American Journal of Clinical Nutrition 65, 13-19.

Rosado JL (1999) Separate and joint effects of micronutrient deficiencies on linear growth. Journal of Nutrition 129, 531S-533S.

Sandstead HH, Penland JG, Alcock NW, Dayal HH, Chen XC, Li JS, Zhao F \& Yang JJ (1998) Effects of repletion with zinc and other micronutrients on neuropsychologic performance and growth of Chinese children. American Journal of Clinical Nutrition 68 (suppl), 470S-475S.

Santos LMP, Dacto JM, Ascuitti LS \& Dricot-d'Ams C (1983) Xeropthalmia in the state of Paraiba, northeast of Brazil: clinical findings. American Journal of Nutrition 38, 139-144.

Simondon KB, Gartner A, Berger J, Cornu A, Massamba JP, Miguel JS, Missotte CLI, Simondon F, Traissac P, Delpeuch F \& Maire B (1996) Effect of early, short-term supplementation on weight and linear growth of 4-7 month old infants in developing countries: a four country randomized trial. American Journal of Clinical Nutrition 64, 537-545.

Singla PN, Chand P, Kumar A \& Kachhawaha JS (1996) Serum, zinc and copper levels in children with protein energy malnutrition. Indian Journal of Pediatrics 63, 199-203.

Singla PN, Chand P, Kumar A \& Kachhawaka JS (1998) Serum magnesium levels in protein energy malnutrition. Journal of Tropical Pediatrics 44, 117-119.

Stuijvenberg ME, Kvalsvig JD, Faber M, Kruger M, Kenoyer DG $\&$ Benade AJS (1999) Effect of iron-, iodine-, and $\beta$-carotenefortified biscuits on the micronutrient status of primary school children: a randomized controlled trial. American Journal of Clinical Nutrition 69, 497-503.

Subotzky EF, Heese HD, Sive AA, Depster WS, Sacks R \& Malan H (1992) Plasma zinc, copper, selenium, ferritin and whole blood manganese concentrations in children with kwashiorkor in the acute stage and during refeeding. Annals of Tropical Pediatrics 12, 13-22.

Tanzer F \& Ozalp I (1988) Plasma and leukocyte zinc and copper levels in patients with protein energy malnutrition. Journal of Tropical Pediatrics 34, 306-308.

Thu BD, Schultink W, Dillon D, Gross R, Leswara ND \& Khoi HH (1999) Effect of daily and weekly micronutrient supplementation on micronutrient deficiencies and growth in young Vietnamese children. American Journal of Clinical Nutrition 69, 80-86.

Umeta M, West CE, Haidar J, Deurenberg P \& Hautvast GAJ (2000) Zinc supplementation and stunted infants in Ethiopia: a randomized controlled trial. Lancet 355, 2021-2026.

Waterlow JC, Ashworth A \& Griffiths M (1980) Faltering in infants' growth in less developed countries. Lancet 2, 1176-1178.

West KP Jr, Djunaedi E, Pandji A, Kusdiono, Tarwotjo I, Sommer A \& The Aceh Study Group (1988) Vitamin A supplementation and growth: a randomized community trial. American Journal of Clinical Nutrition 48, 1257-1264.

West KP Jr, LeClerq SC, Shrestha SR, Wu Lee SF, Pradhan EK, Khatry SK, Katz J, Adhikari R \& Sommer A (1997) Effect of vitamin A on growth of vitamin A deficient children: field studies in Nepal. Journal of Nutrition 127, 1957-1965.

World Health Organization (1996) Trace elements in human nutrition and health. WHO, Geneva. 